\title{
Adenovirus and the Cornea: More Than Meets the Eye
}

\author{
Jaya Rajaiya, Amrita Saha, Ashrafali M. Ismail $\mathbb{C}$, Xiaohong Zhou, Ting Su and James Chodosh *(1) \\ Massachusetts Eye and Ear, Harvard Medical School, 243 Charles Street, Boston, MA 02114, USA; \\ jaya_rajaiya@meei.harvard.edu (J.R.); amrita_saha@meei.harvard.edu (A.S.); \\ mohamed_ismail@meei.harvard.edu (A.M.I.); xiaohong_zhou@meei.harvard.edu (X.Z.); \\ ting_su-mail@meei.harvard.edu (T.S.) \\ * Correspondence: james_chodosh@meei.harvard.edu
}

Citation: Rajaiya, J.; Saha, A.; Ismail, A.M.; Zhou, X.; Su, T.; Chodosh, J. Adenovirus and the Cornea: More Than Meets the Eye. Viruses 2021, 13, 293. https://doi.org/10.3390/ v13020293

Academic Editors: Annasara Lenman and Niklas Arnberg

Received: 18 January 2021

Accepted: 10 February 2021

Published: 13 February 2021

Publisher's Note: MDPI stays neutral with regard to jurisdictional claims in published maps and institutional affiliations.

Copyright: (c) 2021 by the authors. Licensee MDPI, Basel, Switzerland. This article is an open access article distributed under the terms and conditions of the Creative Commons Attribution (CC BY) license (https:/ / creativecommons.org/licenses/by/ $4.0 /)$.

\begin{abstract}
Human adenoviruses cause disease at multiple mucosal sites, including the respiratory, gastrointestinal, and genitourinary tracts, and are common agents of conjunctivitis. One site of infection that has received sparse attention is the cornea, a transparent tissue and the window of the eye. While most adenovirus infections are self-limited, corneal inflammation (keratitis) due to adenovirus can persist or recur for months to years after infection, leading to reduced vision, discomfort, and light sensitivity. Topical corticosteroids effectively suppress late adenovirus keratitis but are associated with vision-threatening side effects. In this short review, we summarize current knowledge on infection of the cornea by adenoviruses, including corneal epithelial cell receptors and determinants of corneal tropism. We briefly discuss mechanisms of stromal keratitis due to adenovirus infection, and review an emerging therapy to mitigate adenovirus corneal infections based on evolving knowledge of corneal epithelial receptor usage.
\end{abstract}

Keywords: adenovirus; epidemic keratoconjunctivitis; human corneal epithelium; viral receptor

\section{Introduction}

The human adenovirus (HAdV) is a ubiquitous pathogen that has contributed much to current knowledge of molecular biology, leading to critical revelations about the cell cycle and RNA splicing, among other discoveries [1]. Infections with HAdV are a significant source of morbidity and mortality, world-wide and at all ages, through readily transmittable infections at mucosal sites [2]. Infection may be especially lethal in infants [3-6] and the immune compromised [7-10], but can also cause fatal acute respiratory distress syndrome in healthy adults $[11,12]$. HAdVs segregate phylogenetically into seven species (A-G), with 104 types [13,14]; 73 of the 104 fall within species D. The major corneal pathogens, all within species D, are HAdV-D8, 37, 53, 54, 56, 64 (previously typed as 19a), 82, and 85 (the latter two recently emerged) [15-25]. In this brief review, we discuss mechanisms of infection of the corneal epithelium by HAdVs, the immunologic manifestations of corneal infection, and recent approaches to antiviral therapy.

\section{Adenoviral Eye Infection}

HAdV infections of the eye are common, and the most frequent cause of viral conjunctivitis [26,27]. HAdV ocular infections manifest as either simple follicular conjunctivitis, pharyngoconjunctival fever, or epidemic keratoconjunctivitis (EKC). The first two are selflimited and do not involve the cornea. In contrast, corneal involvement is the sine qua non of EKC, and can become chronic and/or recurrent in $\frac{1}{4}-\frac{1}{2}$ of cases [28,29], with no specific therapy available [22]. The clinical signs of acute EKC include follicular conjunctivitis and preauricular lymphadenopathy, both common to other viral infections, but with a more explosive clinical course [30,31]. The contralateral eye in EKC is affected in $~ 70 \%$ of cases [32]. Inflammatory conjunctival membranes form in $\frac{1}{4}-\frac{1}{2}$ of those with EKC [28,31]; if untreated, these membranes become incorporated into host tissue and can form scars that may restrict eye movement and/or cause symptoms of dry eye [33]. 
Conjunctival membrane formation and keratitis distinguish EKC from other ocular adenovirus infections $[31,34,35]$. The epithelial keratitis in EKC presents within the first few days of symptoms with either punctate or large, geographic-shaped epithelial erosions [34], and typically resolves in several days. However, stromal keratitis then ensues-in 60\% of cases in a recent large study [21]. Characteristic multifocal, subepithelial, leukocytic infiltrates appear in the corneal stroma at 14-21 days after onset of the clinical signs of infection [21]. These infiltrates most commonly resolve within a few weeks of onset, but in a significant proportion of persons will persist or recur for months to years $[28,29,36]$. In one study, $47 \%$ still had signs of stromal keratitis 2 years after onset of infection [29]. Adenovirus-associated stromal keratitis leads to foreign body sensation and symptoms of glare, irregular astigmatism, and blurred vision [37], and can cause permanent corneal scarring [38].

\section{The Cornea Facsimile}

Animal models to study adenoviral pathogenesis have been limited by the specificity of HAdVs for human cells; mouse models can be used only to study innate immune responses to the virion [39-41]. To determine the pathogenesis of adenovirus stromal keratitis, Rajaiya and coworkers [42] modified a previously described 3-D in vitro model of the human cornea, the "human corneal facsimile" [43]. In this model, primary cultured human keratocytes (the fibroblast-like resident cells of the corneal stroma) were mixed with type I collagen in 3- $\mu \mathrm{m}$ pore size transwell inserts, and overlayed with Matrigel ${ }^{\circledR}$ [44], an epithelial basement membrane-like layer, in order to simulate a human corneal stroma and epithelial basement membrane, respectively. When infected from the (upper) Matrigel side with HAdV-D37, CXCL8 expressed by infected keratocytes co-localized with heparan sulfate within the Matrigel in a multifocal pattern. When leukocytes derived from human peripheral blood were placed in the media beneath the inserts, neutrophils migrated upwards, against gravity, to foci of CXCL8 deposition, mimicking the subepithelial corneal infiltrates characteristic of human patients with EKC. These data support a mechanism for stromal keratitis in EKC in which infected keratocytes express chemokines that deposit at negatively charged moieties in the corneal epithelial basement membrane. However, evidence to support infection of corneal stromal cells in the intact human cornea by adenovirus during EKC is lacking. Regardless, successful replication of HAdV in the corneal epithelium in the early stages of EKC is very likely required for the later development of stromal keratitis [31,45].

\section{Corneal Epithelial Cell Tropism and Receptors}

An abundance of evidence supports corneal epithelial cell infection by HAdVs. In a large clinical series of EKC cases $(n=92)$, Imre and colleagues showed typical adenovirus inclusions in $85 \%$ of corneal epithelial scrapings of studied patients [46]. Dawson et al. then reported adenovirus-like particles within corneal epithelial cells from scrapings taken from a patient with EKC who was culture positive for HAdV-D8 [31]. Maudgal used impression cytology of the corneal epithelium in 12 patients with EKC, all culture positive for adenovirus, to show typical intracellular virus inclusions [45]. Chodosh and coworkers reported positive cultures for adenovirus from corneal scrapings obtained from six patients with epithelial keratitis [34]. They further showed that HAdV-D8, the most common cause of EKC world-wide [21], can replicate in primary human corneal epithelial cells cultured in vitro [34].

The tropism of particular HAdVs for corneal epithelial cells could account for the limited number of HAdV types associated with EKC [21]. However, Xiao and coworkers [47] successfully infected an SV40 immortalized corneal epithelial cell line derived by Araki-Sasaki and colleagues [48] with numerous different HAdV types, including some not typically associated with EKC. In this cell line, HAdV-C2, not known to cause EKC, grew to considerably higher titers than HAdV-D64, a common EKC pathogen. However, the opposite result-greatly favoring HAdV-D64 replication, was seen upon infection of 
whole human donor corneas in organotypic culture, and also when the cells were cultured on a vitronectin substrate. These data suggested that the SV40 immortalized cells grown on standard tissue culture ware do not adequately recapitulate human corneal epithelium in vivo. In contrast, experimental infections of a line of human corneal epithelial cells immortalized by transfection of human telomerase reverse transcriptase (hTERT) [49] more closely matched known clinical associations of specific types with EKC. In those studies, hTERT-immortalized human corneal epithelial cells were permissive of viral replication only for those types associated with EKC, while not permitting infection by types not associated with EKC $[17,18,50]$.

As with all mucosa, the eye is bathed in secretions with antiviral components, [51] and the preocular tear film must be successfully negotiated by any pathogen for infection to occur. Menon and coworkers also showed a role in HAdV tropism for the membrane associated mucin-rich glycocalyx covering the apical surface of the corneal epithelium [52]. The cornea-tropic HAdV-D37, but not HAdV-D19, induced the release of MUC16 ectodomain in corneal epithelial cells [52], and this reduced the barrier to corneal epithelial cell infection. The preocular tear film may also enhance [53] or inhibit [54] adenoviral entry, the latter reportedly mediated by glycosaminoglycans in tears. Suranim, a glycosaminoglycan mimetic, inhibited the attachment of HAdV-D37 to SV40-immortalized human corneal epithelial cells, and was predicted to also block attachment of other EKC-associated viruses within HAdV-D [55].

The primary ligand for adenovirus binding to its target cell is the trimeric fiber protein $[56,57]$. The fiber extends outward from each penton base capsomer, located at the 12 apices of the icosahedral capsid. The most distal component of the fiber, the "knob", has been mapped for specific sites of receptor binding [56,58-67] to several cell surface molecules. The specific receptor utilized depends on the structure and amino acid signatures displayed on the fiber knob $[59,68]$, and has impact downstream on intracellular trafficking and inflammation $[69,70]$. Receptors previously reported for HAdVs include the CoxsackieAdenovirus receptor [56,71], sialic acid [72-75], GD1a glycan [58], CD46 [76,77], desmoglein 2 [78], and other constitutive cell surface molecules [79-81]. Both GD1a glycan and CD46 were previously reported to bind those HAdVs associated with EKC [58,72,73,75,82,83].

Recent evidence has further clarified receptor-mediated entry of those types within HAdV-D associated with EKC, resulting in the first potential viral entry-based therapy for acute infection (Figure 1). As discussed briefly above, it was shown that HAdV-D37 binds to sialic acid [72-75], and that binding in vitro to corneal epithelial cells can be inhibited by multivalent sialic acid conjugates [84]. More recently, it was demonstrated that HAdV-D37 binds specifically to two sialic acids present on GD1a glycan [58]. These studies used the same SV40 immortalized corneal epithelial cell line [48] discussed above. Subsequent work showed that some but not all of the EKC-associated HAdVs bind to sialic acid-expressing cell surface glycans [85], and that various multivalent sialic acid constructs could block binding [84,86-91]. Sites on the fiber knob that bind to the various potential adenovirus receptors have been mapped in exquisitely detailed structural studies [92]. Binding is not only specific to HAdV species [76], but also differs within HAdV species $[65,77,93,94]$. A recent study of the fiber knobs of HAdV-D revealed a distinct phylogenetic clade encompassing those associated with EKC [95]. Specifically, an association with EKC, and by inference with corneal epithelial cell tropism, was predicted by a lysine or alanine at amino acid residue 240 on the knob. 


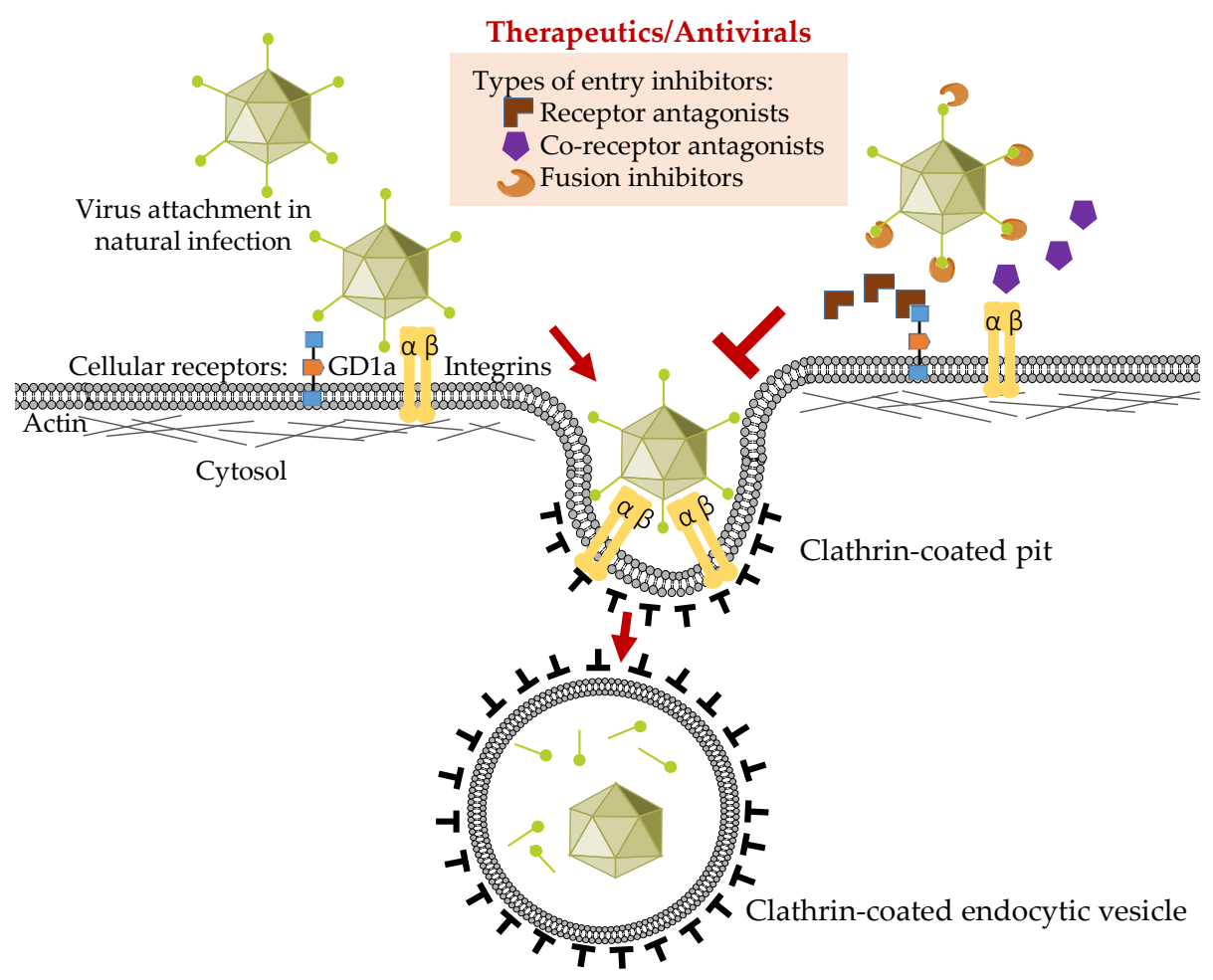

Figure 1. Schematic representation of the adenovirus entry process in corneal epithelial cells and possible viral entry inhibitors.

In the most widely cited paradigm for adenoviral entry (Figure 1), primary binding of the fiber knob to its receptor is followed by secondary contact between an arginineglycine-aspartic acid (RGD) motif in each penton base protein with host cell integrins including $\alpha_{\mathrm{v}} \beta_{3}, \alpha_{\mathrm{v}} \beta_{5}$, and $\alpha_{\mathrm{v}} \beta_{1}$ [96-98] (and for human corneal epithelial cells, $\alpha_{\mathrm{v}} \beta_{1}$ and $\alpha_{3} \beta_{1}$ [98]). This in turn induces aggregation of the integrins [99,100], which results in changes in the integrin conformation [101] and autophosphorylation [102], and leads to activation of focal adhesion kinase $[103,104]$ and Src kinase $[105,106]$. These changes in intracellular signaling in turn activate clathrin-mediated endocytosis $[103,107,108]$. For the non-EKC-associated HAdV-D9, the fiber is relatively short and allows direct interaction with host cell integrins without fiber knob/receptor engagement $[74,109]$. Recently, the hexon protein of the EKC pathogen, HAdV-D56 [17], was shown to bind directly to CD46; soluble CD46 also inhibited binding of 16 out of 17 HAdV-D types tested [110]. To add complexity to this story, CD46 binding has been associated specifically with internalization by clathrin-coated pits, but when cross-linked by a multivalent ligand, CD46 binding can lead to entry by macropinocytosis [111].

Although the mechanistic connection between binding of the adenovirus fiber knob to a cell surface receptor and secondary aggregation of cell membrane integrins is relatively clear, the molecular events that connect integrin aggregation to endocytosis have not been clarified in corneal epithelial cells. Lee and coworkers recently showed that entry of HAdV-D37 occurs by a noncanonical clathrin-mediated entry pathway in both hTERTimmortalized human corneal epithelial cells, and in primary cultured human corneal epithelial cells [112]. More studies are needed, but in human keratinocytes, $\alpha_{v} \beta_{5}$ can cluster in clathrin-enriched foci [113]. Aggregation of integrin $\beta 3$ by RGD motifs can recruit clathrin endocytic machinery [114], and clathrin can mediate endocytosis of integrins for recycling [115]. These findings suggest future avenues of research.

In summary, existing evidence implicates corneal epithelial cells as key to adenoviral corneal pathogenesis, with likely contributions from keratocytes and resident bone marrow derived cells in the corneal stroma to the immunopathology of EKC. Recent discoveries 
related to corneal epithelial cell entry by HAdV-Ds suggest hope for the development of an effective therapy to mitigate immunopathology in EKC.

Author Contributions: Conceptualization, J.R. and J.C.; writing-original draft preparation, J.R. and J.C.; writing - review and editing, J.R., A.S., A.M.I., X.Z., T.S., and J.C.; funding acquisition, J.R. and J.C. All authors have read and agreed to the published version of the manuscript.

Funding: This research was funded by National Institutes of Health grants EY013124, EY021558, and EY014104, and an unrestricted grant to the Department of Ophthalmology, Harvard Medical School from Research to Prevent Blindness, Inc., New York, NY, USA.

Institutional Review Board Statement: Not applicable.

Informed Consent Statement: Not applicable.

Data Availability Statement: No new data were created or analyzed in this study. Data sharing is not applicable to this article.

Conflicts of Interest: The authors declare no conflict of interest. The funders had no role in the design of the study; in the collection, analyses, or interpretation of data; in the writing of the manuscript, or in the decision to publish the results.

\section{References}

1. Nemerow, G.; Flint, J. Lessons learned from adenovirus (1970-2019). FEBS Lett. 2019, 593, 3395-3418. [CrossRef] [PubMed]

2. Shenk, T. Adenoviridae: The Viruses and Their Replication. In Fields Virology; Fields, B.N., Knipe, D.M., Howley, P.M., Eds.; Lippincott-Raven: Philadelphia, PA, USA, 1996; Volume 2, pp. 2111-2148.

3. Bhat, A.M.; Meny, R.G.; Aranas, E.A.; Yehia, F. Fatal adenoviral (type 7) respiratory disease in neonates. Clin. Pediatr. 1984, 23, 409-411. [CrossRef]

4. Henquell, C.; Boeuf, B.; Mirand, A.; Bacher, C.; Traore, O.; Dechelotte, P.; Labbe, A.; Bailly, J.L.; Peigue-Lafeuille, H. Fatal adenovirus infection in a neonate and transmission to health-care workers. J. Clin. Virol. 2009, 45, 345-348. [CrossRef] [PubMed]

5. Chodosh, J. Neonatal Intensive Care Eye. Ophthalmology 2019, 126, 144-145. [CrossRef]

6. Sammons, J.S.; Graf, E.H.; Townsend, S.; Hoegg, C.L.; Smathers, S.A.; Coffin, S.E.; Williams, K.; Mitchell, S.L.; Nawab, U.; Munson, D.; et al. Outbreak of Adenovirus in a Neonatal Intensive Care Unit: Critical Importance of Equipment Cleaning During Inpatient Ophthalmologic Examinations. Ophthalmology 2019, 126, 137-143. [CrossRef]

7. Lion, T. Adenovirus persistence, reactivation, and clinical management. FEBS Lett. 2019, 593, 3571-3582. [CrossRef] [PubMed]

8. Lion, T. Adenovirus infections in immunocompetent and immunocompromised patients. Clin. Microbiol. Rev. 2014, 27, 441-462. [CrossRef]

9. Bhanthumkosol, D. Fatal adenovirus infections in infants probably infected with HIV. J. Med. Assoc. Thail. 1998, 81, $214-222$.

10. Wallot, M.A.; Dohna-Schwake, C.; Auth, M.; Nadalin, S.; Fiedler, M.; Malago, M.; Broelsch, C.; Voit, T. Disseminated adenovirus infection with respiratory failure in pediatric liver transplant recipients: Impact of intravenous cidofovir and inhaled nitric oxide. Pediatr. Transplant. 2006, 10, 121-127. [CrossRef]

11. Ryu, J.S.; Cho, J.H.; Han, H.S.; Jung, M.H.; Yoon, Y.H.; Song, E.S.; Lee, J.Y.; Kim, S.Y.; Lee, K.W.; Kwak, S.M.; et al. Acute respiratory distress syndrome induced by adenovirus in an otherwise healthy woman. Yonsei Med. J. 2003, 44, 732-735. [CrossRef]

12. Kujawski, S.A.; Lu, X.; Schneider, E.; Blythe, D.; Boktor, S.; Farrehi, J.; Haupt, T.; McBride, D.; Stephens, E.; Sakthivel, S.K.; et al. Outbreaks of adenovirus-associated respiratory illness on five college campuses in the United States. Clin. Infect. Dis. 2020. [CrossRef]

13. Ismail, A.M.; Zhou, X.; Dyer, D.W.; Seto, D.; Rajaiya, J.; Chodosh, J. Genomic foundations of evolution and ocular pathogenesis in human adenovirus species D. FEBS Lett. 2019, 593, 3583-3608. [CrossRef]

14. Ismail, A.M.; Cui, T.; Dommaraju, K.; Singh, G.; Dehghan, S.; Seto, J.; Shrivastava, S.; Fedorova, N.B.; Gupta, N.; Stockwell, T.B.; et al. Genomic analysis of a large set of currently-and historically-important human adenovirus pathogens. Emerg. Microbes Infect. 2018, 7, 10. [CrossRef] [PubMed]

15. Walsh, M.P.; Chintakuntlawar, A.; Robinson, C.M.; Madisch, I.; Harrach, B.; Hudson, N.R.; Schnurr, D.; Heim, A.; Chodosh, J.; Seto, D; ; et al. Evidence of molecular evolution driven by recombination events influencing tropism in a novel human adenovirus that causes epidemic keratoconjunctivitis. PLoS ONE 2009, 4, e5635. [CrossRef]

16. Ishiko, H.; Aoki, K. Spread of epidemic keratoconjunctivitis due to a novel serotype of human adenovirus in Japan. J. Clin. Microbiol. 2009, 47, 2678-2679. [CrossRef]

17. Robinson, C.M.; Singh, G.; Henquell, C.; Walsh, M.P.; Peigue-Lafeuille, H.; Seto, D.; Jones, M.S.; Dyer, D.W.; Chodosh, J. Computational analysis and identification of an emergent human adenovirus pathogen implicated in a respiratory fatality. Virology 2011, 409, 141-147. [CrossRef] [PubMed] 
18. Zhou, X.; Robinson, C.M.; Rajaiya, J.; Dehghan, S.; Seto, D.; Jones, M.S.; Dyer, D.W.; Chodosh, J. Analysis of human adenovirus type 19 associated with epidemic keratoconjunctivitis and its reclassification as adenovirus type 64. Investig. Ophthalmol. Vis. Sci. 2012, 53, 2804-2811. [CrossRef]

19. Robinson, C.M.; Shariati, F.; Gillaspy, A.F.; Dyer, D.W.; Chodosh, J. Genomic and bioinformatics analysis of human adenovirus type 37: New insights into corneal tropism. BMC Genom. 2008, 9, 213. [CrossRef]

20. Robinson, C.M.; Shariati, F.; Zaitshik, J.; Gillaspy, A.F.; Dyer, D.W.; Chodosh, J. Human adenovirus type 19: Genomic and bioinformatics analysis of a keratoconjunctivitis isolate. Virus Res. 2009, 139, 122-126. [CrossRef]

21. Lee, C.S.; Lee, A.Y.; Akileswaran, L.; Stroman, D.; Najafi-Tagol, K.; Kleiboeker, S.; Chodosh, J.; Magaret, A.; Wald, A.; Van Gelder, R.N.; et al. Determinants of Outcomes of Adenoviral Keratoconjunctivitis. Ophthalmology 2018, 125, 1344-1353. [CrossRef] [PubMed]

22. Jonas, R.A.; Ung, L.; Rajaiya, J.; Chodosh, J. Mystery eye: Human adenovirus and the enigma of epidemic keratoconjunctivitis. Prog. Retin. Eye Res. 2020, 76, 100826. [CrossRef] [PubMed]

23. Hashimoto, S.; Gonzalez, G.; Harada, S.; Oosako, H.; Hanaoka, N.; Hinokuma, R.; Fujimoto, T. Recombinant type Human mastadenovirus D85 associated with epidemic keratoconjunctivitis since 2015 in Japan. J. Med. Virol. 2018, 90, 881-889. [CrossRef]

24. Kaneko, H.; Hanaoka, N.; Konagaya, M.; Kobayashi, M.; Nakagawa, H.; Hatano, H.; Ikuta, K.; Sekiryu, T.; Fujimoto, T. Five Cases of Epidemic Keratoconjunctivitis Due to Human Adenovirus Type 85 in Fukushima, Japan. Jpn. J. Infect. Dis. 2020, 73, 316-319. [CrossRef]

25. Gonzalez, G.; Aoki, K.; Yawata, N.; Kitaichi, N. Epidemic kerato-conjunctivitis; new era of required clinical practices due to the emergence of novel recombinant types in human mastadenovirus D. J. Clin. Ophthalmol. Eye Disord. 2017, 1, 2014.

26. Azari, A.A.; Barney, N.P. Conjunctivitis: A systematic review of diagnosis and treatment. JAMA 2013, 310, 1721-1729. [CrossRef]

27. Shields, T.; Sloane, P.D. A comparison of eye problems in primary care and ophthalmology practices. Fam. Med. 1991, 23, 544-546.

28. Butt, A.L.; Chodosh, J. Adenoviral keratoconjunctivitis in a tertiary care eye clinic. Cornea 2006, 25, 199-202. [CrossRef]

29. Freyler, H.; Sehorst, W. The fate of corneal infiltrations in cases of epidemic keratoconjunctivitis. A follow-up study over two and a half years. Wien. Klin. Wochenschr. 1976, 88, 341-343.

30. Chodosh, J. Epidemic Keratoconjunctivitis. In Atlas of Clinical Wisdom: Cornea, Refractive and External Disease, 1st ed.; Melki, S., Ed.; Slack: Thorofare, NJ, USA, 2011; pp. 91-96.

31. Dawson, C.R.; Hanna, L.; Togni, B. Adenovirus type 8 infections in the United States. IV. Observations on the pathogenesis of lesions in severe eye disease. Arch. Ophthalmol. 1972, 87, 258-268. [CrossRef] [PubMed]

32. Kimura, R.; Migita, H.; Kadonosono, K.; Uchio, E. Is it possible to detect the presence of adenovirus in conjunctiva before the onset of conjunctivitis? Acta Ophthalmol. 2009, 87, 44-47. [CrossRef]

33. Chintakuntlawar, A.V.; Chodosh, J. Cellular and tissue architecture of conjunctival membranes in epidemic keratoconjunctivitis. Ocul. Immunol. Inflamm. 2010, 18, 341-345. [CrossRef]

34. Chodosh, J.; Miller, D.; Stroop, W.G.; Pflugfelder, S.C. Adenovirus epithelial keratitis. Cornea 1995, 14, 167-174. [CrossRef]

35. Hogan, M.J.; Crawford, J.W. Epidemic Keratoconjunctivitis: (Superficial Punctate Keratitis, Keratitis Subepithelialis, Keratitis Maculosa, Keratitis Nummularis) With a Review of the Literature and a Report of 125 Cases. Am. J. Ophthalmol. 1942, 25, 1059-1078. [CrossRef]

36. Pettit, T.H.; Holland, G.N. Chronic keratoconjunctivitis associated with ocular adenovirus infection. Am. J. Ophthalmol. 1979, 88, 748-751. [CrossRef]

37. Aydin Kurna, S.; Altun, A.; Oflaz, A.; Karatay Arsan, A. Evaluation of the impact of persistent subepithelial corneal infiltrations on the visual performance and corneal optical quality after epidemic keratoconjunctivitis. Acta Ophthalmol. 2015, 93, 377-382. [CrossRef]

38. Gokhale, N.S. Anterior segment optical coherence tomography to differentiate adenoviral subepithelial infiltrates and scars. Indian J. Ophthalmol. 2019, 67, 1725. [CrossRef]

39. Ginsberg, H.S.; Moldawer, L.L.; Sehgal, P.B.; Redington, M.; Kilian, P.L.; Chanock, R.M.; Prince, G.A. A mouse model for investigating the molecular pathogenesis of adenovirus pneumonia. Proc. Natl. Acad. Sci. USA 1991, 88, 1651-1655. [CrossRef] [PubMed]

40. Chintakuntlawar, A.V.; Astley, R.; Chodosh, J. Adenovirus type 37 keratitis in the C57BL/6J mouse. Investig. Ophthalmol. Vis. Sci. 2007, 48, 781-788. [CrossRef] [PubMed]

41. Chodosh, J. Human adenovirus type 37 and the BALB/c mouse: Progress toward a restricted adenovirus keratitis model (an American Ophthalmological Society thesis). Trans. Am. Ophthalmol. Soc. 2006, 104, 346-365.

42. Rajaiya, J.; Zhou, X.; Barequet, I.; Gilmore, M.S.; Chodosh, J. Novel model of innate immunity in corneal infection. In Vitro Cell. Dev. Biol. Anim. 2015, 51, 827-834. [CrossRef] [PubMed]

43. Chodosh, J.; Astley, R.A.; Butler, M.G.; Kennedy, R.C. Adenovirus keratitis: A role for interleukin-8. Investig. Ophthalmol. Vis. Sci. 2000, 41, 783-789.

44. Kleinman, H.K.; Martin, G.R. Matrigel: Basement membrane matrix with biological activity. Semin. Cancer Biol. 2005, 15, 378-386. [CrossRef]

45. Maudgal, P.C. Cytopathology of adenovirus keratitis by replica technique. Br. J. Ophthalmol. 1990, 74, 670-675. [CrossRef]

46. Imre, G.; Korchmaros, I.; Opauszki, A. On epidemic keratoconjunctivitis. Orvos. Hetil. 1963, 104, $353-357$. 
47. Xiao, J.; Natarajan, K.; Rajala, M.S.; Astley, R.A.; Ramadan, R.T.; Chodosh, J. Vitronectin: A possible determinant of adenovirus type 19 tropism for human corneal epithelium. Am. J. Ophthalmol. 2005, 140, 363-369. [CrossRef] [PubMed]

48. Araki-Sasaki, K.; Ohashi, Y.; Sasabe, T.; Hayashi, K.; Watanabe, H.; Tano, Y.; Handa, H. An SV40-immortalized human corneal epithelial cell line and its characterization. Investig. Ophthalmol. Vis. Sci. 1995, 36, 614-621.

49. Robertson, D.M.; Li, L.; Fisher, S.; Pearce, V.P.; Shay, J.W.; Wright, W.E.; Cavanagh, H.D.; Jester, J.V. Characterization of growth and differentiation in a telomerase-immortalized human corneal epithelial cell line. Investig. Ophthalmol. Vis. Sci. 2005, 46, 470-478. [CrossRef]

50. Singh, G.; Zhou, X.; Lee, J.Y.; Yousuf, M.A.; Ramke, M.; Ismail, A.M.; Lee, J.S.; Robinson, C.M.; Seto, D.; Dyer, D.W.; et al. Recombination of the epsilon determinant and corneal tropism: Human adenovirus species D types 15, 29, 56, and 69. Virology 2015, 485, 452-459. [CrossRef] [PubMed]

51. McDermott, A.M. Antimicrobial compounds in tears. Exp. Eye Res. 2013, 117, 53-61. [CrossRef]

52. Menon, B.B.; Zhou, X.; Spurr-Michaud, S.; Rajaiya, J.; Chodosh, J.; Gipson, I.K. Epidemic Keratoconjunctivitis-Causing Adenoviruses Induce MUC16 Ectodomain Release To Infect Ocular Surface Epithelial Cells. mSphere 2016, 1. [CrossRef]

53. Jonsson, M.I.; Lenman, A.E.; Frangsmyr, L.; Nyberg, C.; Abdullahi, M.; Arnberg, N. Coagulation factors IX and X enhance binding and infection of adenovirus types 5 and 31 in human epithelial cells. J. Virol. 2009, 83, 3816-3825. [CrossRef]

54. Chandra, N.; Liu, Y.; Liu, J.X.; Frangsmyr, L.; Wu, N.; Silva, L.M.; Lindstrom, M.; Chai, W.; Pedrosa Domellof, F.; Feizi, T.; et al. Sulfated Glycosaminoglycans as Viral Decoy Receptors for Human Adenovirus Type 37. Viruses 2019, 11, 247. [CrossRef] [PubMed]

55. Chandra, N.; Frangsmyr, L.; Arnberg, N. Decoy Receptor Interactions as Novel Drug Targets against EKC-Causing Human Adenovirus. Viruses 2019, 11, 242. [CrossRef] [PubMed]

56. Bergelson, J.M.; Cunningham, J.A.; Droguett, G.; Kurt-Jones, E.A.; Krithivas, A.; Hong, J.S.; Horwitz, M.S.; Crowell, R.L.; Finberg, R.W. Isolation of a common receptor for Coxsackie B viruses and adenoviruses 2 and 5. Science 1997, 275, 1320-1323. [CrossRef] [PubMed]

57. Van Raaij, M.J.; Mitraki, A.; Lavigne, G.; Cusack, S. A triple beta-spiral in the adenovirus fibre shaft reveals a new structural motif for a fibrous protein. Nature 1999, 401, 935-938. [CrossRef] [PubMed]

58. Nilsson, E.C.; Storm, R.J.; Bauer, J.; Johansson, S.M.; Lookene, A.; Angstrom, J.; Hedenstrom, M.; Eriksson, T.L.; Frangsmyr, L.; Rinaldi, S.; et al. The GD1a glycan is a cellular receptor for adenoviruses causing epidemic keratoconjunctivitis. Nat. Med. 2011, 17, 105-109. [CrossRef]

59. Burmeister, W.P.; Guilligay, D.; Cusack, S.; Wadell, G.; Arnberg, N. Crystal structure of species D adenovirus fiber knobs and their sialic acid binding sites. J. Virol. 2004, 78, 7727-7736. [CrossRef]

60. Lord, R.; Parsons, M.; Kirby, I.; Beavil, A.; Hunt, J.; Sutton, B.; Santis, G. Analysis of the interaction between RGD-expressing adenovirus type 5 fiber knob domains and alphavbeta3 integrin reveals distinct binding profiles and intracellular trafficking. $J$. Gen. Virol. 2006, 87, 2497-2505. [CrossRef]

61. Kirby, I.; Lord, R.; Davison, E.; Wickham, T.J.; Roelvink, P.W.; Kovesdi, I.; Sutton, B.J.; Santis, G. Adenovirus type 9 fiber knob binds to the coxsackie $B$ virus-adenovirus receptor (CAR) with lower affinity than fiber knobs of other CAR-binding adenovirus serotypes. J. Virol. 2001, 75, 7210-7214. [CrossRef]

62. Kirby, I.; Davison, E.; Beavil, A.J.; Soh, C.P.; Wickham, T.J.; Roelvink, P.W.; Kovesdi, I.; Sutton, B.J.; Santis, G. Identification of contact residues and definition of the CAR-binding site of adenovirus type 5 fiber protein. J. Virol. 2000, 74, 2804-2813. [CrossRef] [PubMed]

63. Persson, B.D.; Reiter, D.M.; Marttila, M.; Mei, Y.F.; Casasnovas, J.M.; Arnberg, N.; Stehle, T. Adenovirus type 11 binding alters the conformation of its receptor CD46. Nat. Struct. Mol. Biol. 2007, 14, 164-166. [CrossRef] [PubMed]

64. Gustafsson, D.J.; Segerman, A.; Lindman, K.; Mei, Y.F.; Wadell, G. The Arg279Gln [corrected] substitution in the adenovirus type 11p (Ad11p) fiber knob abolishes EDTA-resistant binding to A549 and CHO-CD46 cells, converting the phenotype to that of Ad7p. J. Virol. 2006, 80, 1897-1905. [CrossRef] [PubMed]

65. Pache, L.; Venkataraman, S.; Reddy, V.S.; Nemerow, G.R. Structural variations in species B adenovirus fibers impact CD46 association. J. Virol. 2008, 82, 7923-7931. [CrossRef] [PubMed]

66. Pache, L.; Venkataraman, S.; Nemerow, G.R.; Reddy, V.S. Conservation of fiber structure and CD46 usage by subgroup B2 adenoviruses. Virology 2008, 375, 573-579. [CrossRef]

67. Wang, H.; Liaw, Y.C.; Stone, D.; Kalyuzhniy, O.; Amiraslanov, I.; Tuve, S.; Verlinde, C.L.; Shayakhmetov, D.; Stehle, T.; Roffler, S.; et al. Identification of CD46 binding sites within the adenovirus serotype 35 fiber knob. J. Virol. 2007, 81, 12785-12792. [CrossRef]

68. Huang, S.; Reddy, V.; Dasgupta, N.; Nemerow, G.R. A single amino acid in the adenovirus type 37 fiber confers binding to human conjunctival cells. J. Virol. 1999, 73, 2798-2802. [CrossRef]

69. Iacobelli-Martinez, M.; Nepomuceno, R.R.; Connolly, J.; Nemerow, G.R. CD46-utilizing adenoviruses inhibit C/EBPbetadependent expression of proinflammatory cytokines. J. Virol. 2005, 79, 11259-11268. [CrossRef]

70. Teigler, J.E.; Kagan, J.C.; Barouch, D.H. Late endosomal trafficking of alternative serotype adenovirus vaccine vectors augments antiviral innate immunity. J. Virol. 2014, 88, 10354-10363. [CrossRef]

71. Tomko, R.P.; Xu, R.; Philipson, L. HCAR and MCAR: The human and mouse cellular receptors for subgroup C adenoviruses and group B coxsackieviruses. Proc. Natl. Acad. Sci. USA 1997, 94, 3352-3356. [CrossRef] [PubMed] 
72. Arnberg, N.; Edlund, K.; Kidd, A.H.; Wadell, G. Adenovirus type 37 uses sialic acid as a cellular receptor. J. Virol. 2000, 74, 42-48. [CrossRef] [PubMed]

73. Arnberg, N.; Kidd, A.H.; Edlund, K.; Nilsson, J.; Pring-Akerblom, P.; Wadell, G. Adenovirus type 37 binds to cell surface sialic acid through a charge-dependent interaction. Virology 2002, 302, 33-43. [CrossRef]

74. Arnberg, N.; Kidd, A.H.; Edlund, K.; Olfat, F.; Wadell, G. Initial interactions of subgenus D adenoviruses with A549 cellular receptors: Sialic acid versus alpha(v) integrins. J. Virol. 2000, 74, 7691-7693. [CrossRef]

75. Arnberg, N.; Pring-Akerblom, P.; Wadell, G. Adenovirus type 37 uses sialic acid as a cellular receptor on Chang C cells. J. Virol. 2002, 76, 8834-8841. [CrossRef] [PubMed]

76. Gaggar, A.; Shayakhmetov, D.M.; Lieber, A. CD46 is a cellular receptor for group B adenoviruses. Nat. Med. 2003, 9, 1408-1412. [CrossRef] [PubMed]

77. Marttila, M.; Persson, D.; Gustafsson, D.; Liszewski, M.K.; Atkinson, J.P.; Wadell, G.; Arnberg, N. CD46 is a cellular receptor for all species B adenoviruses except types 3 and 7. J. Virol. 2005, 79, 14429-14436. [CrossRef] [PubMed]

78. Wang, H.; Li, Z.Y.; Liu, Y.; Persson, J.; Beyer, I.; Moller, T.; Koyuncu, D.; Drescher, M.R.; Strauss, R.; Zhang, X.B.; et al. Desmoglein 2 is a receptor for adenovirus serotypes 3, 7, 11 and 14. Nat. Med. 2011, 17, 96-104. [CrossRef]

79. Goosney, D.L.; Nemerow, G.R. Adenovirus infection: Taking the back roads to viral entry. Curr. Biol. 2003, 13, R99-R100. [CrossRef]

80. Nemerow, G.R. Cell receptors involved in adenovirus entry. Virology 2000, 274, 1-4. [CrossRef] [PubMed]

81. Nemerow, G.R.; Pache, L.; Reddy, V.; Stewart, P.L. Insights into adenovirus host cell interactions from structural studies. Virology 2009, 384, 380-388. [CrossRef]

82. Wu, E.; Fernandez, J.; Fleck, S.K.; Von Seggern, D.J.; Huang, S.; Nemerow, G.R. A 50-kDa membrane protein mediates sialic acid-independent binding and infection of conjunctival cells by adenovirus type 37. Virology 2001, 279, 78-89. [CrossRef]

83. Wu, E.; Trauger, S.A.; Pache, L.; Mullen, T.M.; von Seggern, D.J.; Siuzdak, G.; Nemerow, G.R. Membrane cofactor protein is a receptor for adenoviruses associated with epidemic keratoconjunctivitis. J. Virol. 2004, 78, 3897-3905. [CrossRef]

84. Johansson, S.M.; Nilsson, E.C.; Elofsson, M.; Ahlskog, N.; Kihlberg, J.; Arnberg, N. Multivalent sialic acid conjugates inhibit adenovirus type 37 from binding to and infecting human corneal epithelial cells. Antiviral. Res. 2007, 73, 92-100. [CrossRef]

85. Chandra, N.; Frangsmyr, L.; Imhof, S.; Caraballo, R.; Elofsson, M.; Arnberg, N. Sialic Acid-Containing Glycans as Cellular Receptors for Ocular Human Adenoviruses: Implications for Tropism and Treatment. Viruses 2019, 11, 395. [CrossRef]

86. Johansson, E.; Caraballo, R.; Mistry, N.; Zocher, G.; Qian, W.; Andersson, C.D.; Hurdiss, D.L.; Chandra, N.; Thompson, R.; Frangsmyr, L.; et al. Pentavalent Sialic Acid Conjugates Block Coxsackievirus A24 Variant and Human Adenovirus Type 37-Viruses That Cause Highly Contagious Eye Infections. ACS Chem. Biol. 2020, 15, 2683-2691. [CrossRef]

87. Caraballo, R.; Saleeb, M.; Bauer, J.; Liaci, A.M.; Chandra, N.; Storm, R.J.; Frangsmyr, L.; Qian, W.; Stehle, T.; Arnberg, N.; et al. Triazole linker-based trivalent sialic acid inhibitors of adenovirus type 37 infection of human corneal epithelial cells. Org. Biomol. Chem. 2015, 13, 9194-9205. [CrossRef] [PubMed]

88. Spjut, S.; Qian, W.; Bauer, J.; Storm, R.; Frangsmyr, L.; Stehle, T.; Arnberg, N.; Elofsson, M. A potent trivalent sialic acid inhibitor of adenovirus type 37 infection of human corneal cells. Angew. Chem. Int. Ed. Engl. 2011, 50, 6519-6521. [CrossRef] [PubMed]

89. Aplander, K.; Marttila, M.; Manner, S.; Arnberg, N.; Sterner, O.; Ellervik, U. Molecular wipes: Application to epidemic keratoconjuctivitis. J. Med. Chem. 2011, 54, 6670-6675. [CrossRef] [PubMed]

90. Johansson, S.; Nilsson, E.; Qian, W.; Guilligay, D.; Crepin, T.; Cusack, S.; Arnberg, N.; Elofsson, M. Design, synthesis, and evaluation of $\mathrm{N}$-acyl modified sialic acids as inhibitors of adenoviruses causing epidemic keratoconjunctivitis. J. Med. Chem. 2009, 52, 3666-3678. [CrossRef] [PubMed]

91. Johansson, S.M.; Arnberg, N.; Elofsson, M.; Wadell, G.; Kihlberg, J. Multivalent HSA conjugates of 3'-sialyllactose are potent inhibitors of adenoviral cell attachment and infection. ChemBioChem 2005, 6, 358-364. [CrossRef] [PubMed]

92. Stasiak, A.C.; Stehle, T. Human adenovirus binding to host cell receptors: A structural view. Med. Microbiol. Immunol. 2020, 209, 325-333. [CrossRef]

93. Baker, A.T.; Greenshields-Watson, A.; Coughlan, L.; Davies, J.A.; Uusi-Kerttula, H.; Cole, D.K.; Rizkallah, P.J.; Parker, A.L. Diversity within the adenovirus fiber knob hypervariable loops influences primary receptor interactions. Nat. Commun. 2019, 10, 741. [CrossRef] [PubMed]

94. Stencel-Baerenwald, J.E.; Reiss, K.; Reiter, D.M.; Stehle, T.; Dermody, T.S. The sweet spot: Defining virus-sialic acid interactions. Nat. Rev. Microbiol. 2014, 12, 739-749. [CrossRef]

95. Ismail, A.M.; Lee, J.S.; Dyer, D.W.; Seto, D.; Rajaiya, J.; Chodosh, J. Selection Pressure in the Human Adenovirus Fiber Knob Drives Cell Specificity in Epidemic Keratoconjunctivitis. J. Virol. 2016, 90, 9598-9607. [CrossRef] [PubMed]

96. Wickham, T.J.; Mathias, P.; Cheresh, D.A.; Nemerow, G.R. Integrins alpha v beta 3 and alpha v beta 5 promote adenovirus internalization but not virus attachment. Cell 1993, 73, 309-319. [CrossRef]

97. Wickham, T.J.; Filardo, E.J.; Cheresh, D.A.; Nemerow, G.R. Integrin alpha v beta 5 selectively promotes adenovirus mediated cell membrane permeabilization. J. Cell Biol. 1994, 127, 257-264. [CrossRef]

98. Storm, R.J.; Persson, B.D.; Skalman, L.N.; Frangsmyr, L.; Lindstrom, M.; Rankin, G.; Lundmark, R.; Domellof, F.P.; Arnberg, N. Human Adenovirus Type 37 Uses alphaVbeta1 and alpha3beta1 Integrins for Infection of Human Corneal Cells. J. Virol. 2017, 91, e02019-16. [CrossRef] [PubMed] 
99. Veesler, D.; Cupelli, K.; Burger, M.; Graber, P.; Stehle, T.; Johnson, J.E. Single-particle EM reveals plasticity of interactions between the adenovirus penton base and integrin alphaVbeta3. Proc. Natl. Acad. Sci. USA 2014, 111, 8815-8819. [CrossRef]

100. Chiu, C.Y.; Mathias, P.; Nemerow, G.R.; Stewart, P.L. Structure of adenovirus complexed with its internalization receptor, alphavbeta5 integrin. J. Virol. 1999, 73, 6759-6768. [CrossRef]

101. Lindert, S.; Silvestry, M.; Mullen, T.M.; Nemerow, G.R.; Stewart, P.L. Cryo-electron microscopy structure of an adenovirus-integrin complex indicates conformational changes in both penton base and integrin. J. Virol. 2009, 83, 11491-11501. [CrossRef]

102. Fagerholm, S.C.; Hilden, T.J.; Gahmberg, C.G. P marks the spot: Site-specific integrin phosphorylation regulates molecular interactions. Trends Biochem. Sci. 2004, 29, 504-512. [CrossRef]

103. Li, E.; Stupack, D.G.; Brown, S.L.; Klemke, R.; Schlaepfer, D.D.; Nemerow, G.R. Association of p130CAS with phosphatidylinositol3-OH kinase mediates adenovirus cell entry. J. Biol. Chem. 2000, 275, 14729-14735. [CrossRef]

104. Natarajan, K.; Ghalayini, A.J.; Sterling, R.S.; Holbrook, R.M.; Kennedy, R.C.; Chodosh, J. Activation of focal adhesion kinase in adenovirus-infected human corneal fibroblasts. Investig. Ophthalmol. Vis. Sci. 2002, 43, 2685-2690.

105. Rajala, M.S.; Rajala, R.V.; Astley, R.A.; Butt, A.L.; Chodosh, J. Corneal cell survival in adenovirus type 19 infection requires phosphoinositide 3-kinase/Akt activation. J. Virol. 2005, 79, 12332-12341. [CrossRef]

106. Natarajan, K.; Rajala, M.S.; Chodosh, J. Corneal IL-8 expression following adenovirus infection is mediated by c-Src activation in human corneal fibroblasts. J. Immunol. 2003, 170, 6234-6243. [CrossRef] [PubMed]

107. Li, E.; Stupack, D.; Bokoch, G.M.; Nemerow, G.R. Adenovirus endocytosis requires actin cytoskeleton reorganization mediated by Rho family GTPases. J. Virol. 1998, 72, 8806-8812. [CrossRef]

108. Li, E.; Stupack, D.; Klemke, R.; Cheresh, D.A.; Nemerow, G.R. Adenovirus endocytosis via alpha(v) integrins requires phosphoinositide-3-OH kinase. J. Virol. 1998, 72, 2055-2061. [CrossRef]

109. Roelvink, P.W.; Kovesdi, I.; Wickham, T.J. Comparative analysis of adenovirus fiber-cell interaction: Adenovirus type 2 (Ad2) and Ad9 utilize the same cellular fiber receptor but use different binding strategies for attachment. J. Virol. 1996, 70, 7614-7621. [CrossRef]

110. Persson, B.D.; John, L.; Rafie, K.; Strebl, M.; Frangsmyr, L.; Ballmann, M.Z.; Mindler, K.; Havenga, M.; Lemckert, A.; Stehle, T.; et al. Human species D adenovirus hexon capsid protein mediates cell entry through a direct interaction with CD46. Proc. Natl. Acad. Sci. USA 2021, 118. [CrossRef] [PubMed]

111. Crimeen-Irwin, B.; Ellis, S.; Christiansen, D.; Ludford-Menting, M.J.; Milland, J.; Lanteri, M.; Loveland, B.E.; Gerlier, D.; Russell, S.M. Ligand binding determines whether CD46 is internalized by clathrin-coated pits or macropinocytosis. J. Biol. Chem. 2003, 278, 46927-46937. [CrossRef] [PubMed]

112. Lee, J.S.; Mukherjee, S.; Lee, J.Y.; Saha, A.; Chodosh, J.; Painter, D.F.; Rajaiya, J. Entry of Epidemic Keratoconjunctivitis-Associated Human Adenovirus Type 37 in Human Corneal Epithelial Cells. Investig. Ophthalmol. Vis. Sci. 2020, 61, 50. [CrossRef] [PubMed]

113. Zuidema, A.; Wang, W.; Kreft, M.; Te Molder, L.; Hoekman, L.; Bleijerveld, O.B.; Nahidiazar, L.; Janssen, H.; Sonnenberg, A. Mechanisms of integrin alphaVbeta5 clustering in flat clathrin lattices. J. Cell Sci. 2018, 131. [CrossRef] [PubMed]

114. Yu, C.H.; Rafiq, N.B.; Cao, F.; Zhou, Y.; Krishnasamy, A.; Biswas, K.H.; Ravasio, A.; Chen, Z.; Wang, Y.H.; Kawauchi, K.; et al. Integrin-beta3 clusters recruit clathrin-mediated endocytic machinery in the absence of traction force. Nat. Commun. 2015, 6, 8672. [CrossRef] [PubMed]

115. Ezratty, E.J.; Bertaux, C.; Marcantonio, E.E.; Gundersen, G.G. Clathrin mediates integrin endocytosis for focal adhesion disassembly in migrating cells. J. Cell Biol. 2009, 187, 733-747. [CrossRef] [PubMed] 